\title{
Tanggung Jawab dan Perlindungan Hukum Direksi dalam Pengurusan Perseroan Terbatas
}

\author{
Raffles \\ Fakultas Hukum Universitas Jambi \\ raffles@unja.ac.id
}

\section{Abstract}

This article discusses the responsibilities of directors and their legal protection in managing a limited liability company. The responsibility of the directors in managing a limited liability company as regulated in the 2007 Company Law is related to the duties and authority to run the management of the company for the benefit of the company and in accordance with the aims and objectives of the company. To carry out the management of the company, the directors are authorized to carry out the management of the company in accordance with policies deemed appropriate, within the limits specified in the 2007 Company Law and/or articles of association. The responsibility of members of the directors for the company's losses can be seen from the nature of the responsibility is personal and collective. The directors' liability is personal if the loss suffered by the company is due to an error or negligence of the individual members of the board of directors. The responsibility of the directors is collective if the company's losses are caused by an error or negligence in the board's decision or action. Legal protection for directors in company management is provided if the management is based on good faith and prudence, which is recognized as the business judgment rule doctrine. Basically, directors are responsible for all actions and decisions they make, even personal accountability. However, directors can avoid personal liability if they can prove the basis and reasons and are based on good faith and caution.

Keywords: limited liablity company; director; the responsibility; legal protection. 


\section{Abstrak}

Artikel ini membahas tanggung jawab dan perlindungan hukum direksi dalam pengurusan perseroan terbatas. Pertanggungjawaban direksi dalam pengurusan perseroan terbatas sebagaimana diatur dalam UUPT Tahun 2007 terkait dengan tugas dan wewenangnya menjalankan pengurusan perseroan untuk kepentingan perseroan dan sesuai dengan maksud dan tujuan perseroan. Untuk menjalankan pengurusan perseroan, direksi berwenang menjalankan pengurusan perseroan sesuai dengan kebijakan yang dipandang tepat, dalam batas yang ditentukan dalam UUPT Tahun 2007 dan/atau anggaran dasar. Pertanggungjawaban anggota direksi atas kerugian perseroan dilihat dari sifat pertanggungjawabannya bersifat pribadi dan kolektif. Pertanggungjawaban direksi bersifat pribadi apabila kerugian yang dialami perseroan disebabkan kesalahan atau kelalaian individu anggota direksi. Pertanggungjawaban direksi bersifat kolektif apabila kerugian perseroan diakibatkan adanya kesalahan atau kelalaian dalam keputusan atau tindakan dewan direksi. Perlindungan hukum terhadap direksi dalam pengurusan perusahaan diberikan jika pengurusan tersebut didasarkan pada itikad baik dan hati-hati, yang dikenali sebagai doktrin business judgement rule. Pada dasarnya direksi bertanggung jawab atas segala tindakan dan keputusan yang dibuatnya, bahkan pertanggungjawaban pribadi. Namun demikian, direksi dapat terhindar dari tuntutan pertanggungjawaban secara pribadi apabila dapat membuktikan dasar dan alasannya dan didasarkan pada itikad aik dan hati-hati.

Kata kunci: perseroan terbatas; direksi; tanggung jawab; perlindungan hukum.

\section{A. Pendahuluan}

Artikel ini membahas tanggung jawab dan perlindungan hukum direksi dalam pengurusan perseroan terbatas. Persoalan tanggung jawab berkenaan dengan kewajiban seorang individu, dalam hal ini direksi, untuk melaksanakan aktivitas yang ditugaskan kepadanya sebaik mungkin sesuai dengan kemampuannya; ${ }^{1}$ sedangkan persoalan

1 Winardi, Asas-asas Manajemen (Bandung: Alumni, 1983), hlm. 5. Dalam Kamus Besar Bahasa Indonesia (https://kbbi.kemdikbud.go.id/entri/ tanggung\%20jawab), tanggung jawab dimaknai sebagai "keadaan wajib menanggung segala sesuatunya (kalau terjadi apa-apa boleh dituntut, 
perlindungan hukum berkenaan dengan jaminan terlindunginya hakhak individu, dalam hal ini direksi, dalam melaksanakan aktivitasnya. Dua persoalan ini, tanggung jawab dan perlindungan hukum, perlu untuk dibahas lebih lanjut sekaligus dalam kaitannya dengan peran direksi dalam pengurusan perseroan, mengingat peran penting yang dijalankannya sekaligus risiko besar yang juga dihadapinya.

Sebagaimana diketahui, jabatan direksi dalam pengurusan perseroan merupakan jabatan yang penting dan strategis. Direksi adalah organ perseroan terbatas yang melakukan pengurusan perseroan. Hal ini berarti kegiatan operasional perseroan, termasuk konsekuensi yang ditimbulkannya apakah membawa keuntungan atau malah kerugian bagi perseroan, sebagian besar akan bergantung pada dan ditentukan oleh kinerja direksi. Oleh karena itu, terhadap direksi disandarkan tuntutan dan harapan agar menjalankan tugasnya secara profesional serta dilandasi dengan itikad baik dan tanggung jawab.

Berkenaan dengan peran penting dan strategis direksi selaku pengurus perseroan terbatas, Undang-undang Nomor 40 Tahun 2007 tentang Perseroan Terbatas (UUPT Tahun 2007) secara tegas mengatur direksi harus bertanggung jawab atas pengurusan yang dilakukan. ${ }^{2}$ Terhadap tanggung jawab ini, setiap anggota direksi bertanggung jawab secara pribadi atas kerugian perseroan apabila yang bersangkutan bersalah atau lalai menjalankan tugasnya sesuai dengan ketentuan yang berlaku. ${ }^{3}$ Dalam hal direksi perseroan terdiri lebih dari dua anggota atau lebih, maka tanggung jawab atas kerugian perseroan menjadi beban yang harus ditanggung secara renteng oleh setiap anggota direksi. ${ }^{4}$

Namun demikian, UUPT Tahun 2007 juga mengatur bahwa anggota direksi dapat dibebaskan dari tanggung jawab atas kerugian yang dialami perseroan. Pembebasan atau pengecualian dari tanggung

dipersalahkan, diperkarakan, dan sebagainya), dan hak fungsi menerima pembebanan, sebagai akibat sikap pihak sendiri atau pihak lain”.

2 Pasal 97 ayat (1) UUPT Tahun 2007.

3 Pasal 97 ayat (3) UUPT Tahun 2007.

4 Pasal 97 ayat (4) UUPT Tahun 2007. 
jawab ini bisa diperoleh apabila direksi dapat membuktikan empat hal: kerugian yang terjadi bukan karena kesalahan atau kelalaiannya; telah melakukan pengurusan dengan itikad baik dan kehati-hatian; tidak mempunyai benturan kepentingan atas tindakan pengurusan yang mengakibatkan kerugian; dan telah mengambil tindakan untuk mencegah timbul atau berlanjutnya kerugian tersebut. ${ }^{5}$ Dalam hal direksi dibebaskan untuk bertanggung jawab atas kerugian perseroan dikarenakan bisa membuktikan keempat hal itu, maka kondisi ini dapat dikatakan sebagai bentuk perlindungan hukum kepada direksi dalam melakukan pengurusan perseroan.

Perlindungan hukum kepada direksi dalam pengurusan perseroan berupa pembebasan tanggung jawab ini sejalan dengan doktrin business judgment rule dalam hukum perusahaan. Doktrin ini pada intinya berisi ajaran bahwa keputusan-keputusan bisnis tidak bisa dikenai sanksi hukuman, termasuk oleh pengadilan. Hal ini dikarenakan keputusan bisnis memang memiliki risiko kerugian yang bisa jadi peluangnya sama besarnya dengan harapan keuntungan yang diperoleh. Dalam bisnis, tidak ada garansi bahwa keputusan yang diambil akan memberi keuntungan sepenuhnya.

Persoalan tanggung jawab dan perlindungan hukum direksi dalam melakukan pengurusan perseroan sendiri sebenarnya bukanlah hal baru. Terlebih di Indonesia pengaturannya telah ada sejak lama, baik pada UUPT Tahun 2007 maupun UUPT sebelumnya, yaitu Undang-Undang Nomor 1 Tahun 1995. Karena itu, sudah bisa diduga, akan banyak dijumpai karya-karya yang membahasnya, baik dalam buku maupun jurnal, yang sebagiannya sebagaimana terlihat dalam referensi yang dirujuk dalam artikel ini. Karena itu pula, agar membedakan dengan karya-karya lainnya yang juga membahas tanggung jawab dan perlindungan hukum direksi, maka artikel ini memperkaya kajiannya dengan kasus-kasus mutakhir yang sejauh ini relatif belum dijumpai bahasannya dalam jurnal dan apalagi buku, misalnya putusan kasasi Mahkamah Agung pada 9 Maret 2020 yang membebaskan mantan direktur Pertamina Karen Agustina dari

$5 \quad$ Pasal 97 ayat (5) UUPT Tahun 2007. 
tanggung jawab atas kerugian yang dialami perseroan. ${ }^{6}$

Dengan demikian, secara metodologis artikel ini ditulis tidak saja menggunakan bahan hukum berupa peraturan hukum dan literatur terkait perseroan terbatas, melainkan juga putusan hukum pengadilan yang relevan. Beberapa kasus yang nanti dijadikan bahan untuk melihat tanggung jawab dan perlindungan hukum direksi selain kasus mantan direktur Pertamina, ialah perkara perdata Benjamin Widjaja dan Sianna Kusuma Widjaja (keduanya pemegang saham pada PT. Necis Indah Cemerlang) melawan Julius Widjaja (Direksi PT. Necis Indah Cemerlang), Heryati Suryaman (Komisaris PT. Necis Indah Cemerlang), dan PT. Danamon Indonesia, Tbk. dan perkara pidana terhadap terdakwa mantan Direktur Utama PT. Merpati Nusantara Airline, Hotas D.P. Nababan. Pada kasus-kasus ini akan dilihat, bagaimana hakim memaknai pengurusan perseroan oleh direksi dikaitkan dengan tanggung jawab direksi dalam pengurusan tersebut.

Dalam membahas tanggung jawab dan perlindungan hukum direksi dalam pengurusan perseroan, artikel ini setelah ini akan membahas terlebih dahulu perseroan terbatas dan direksi sebagai salah satu organnya. Bahasan ini dimaksudkan untuk memperjelas kedudukan dan peran direksi pada suatu perseroan, yang sesungguhnya penting dan strategis. Bagian berikutnya membahas tanggung jawab direksi dalam pengurusan perseroan terbatas, yang akan menjelaskan mengapa direksi harus bertanggung jawab

6 Sampai artikel ini dilakukan revisi setelah diberi catatan oleh mitra bebestari, putusan kasasi kasus ini belum tersedia dalam direktori putusan Mahkamah Agung, sekalipun putusannya sebenarnya telah dibacakan pada 9 Maret 2020. Karena itu, terkait putusan kasasi kasus ini, artikel ini menggunakan bahan dari media massa yang memberitakan informasi yang disampaikan juru bicara Mahkamah Agung terkait isi putusan kasus tersebut. Putusan pada tingkat sebelumnya juga akan digunakan di sini untuk melihat kejelasan kasus dan dasar pertimbangan hakim yang pada pokoknya berbeda dengan putusan pada kasasi, yaitu Putusan Pengadilan Tindak Pidana Korupsi pada Pengadilan Tinggi DKI Jakarta Nomor 34/Pid. Sus-TPK/2019/PT.DKI. Pada tingkat pertama, Pengadilan Tindak Pidana Korupsi pada Pengadilan Negeri Jakarta Pusat, putusan yang tersedia pada direktori tidak lengkap karena hanya menampilkan amar putusan. 
dalam pengurusan perseroan dan bagaimana pula bentuk tanggung jawabnya. Bagian sesudahnya membahas perlindungan hukum direksi dalam pengurusan perseroan, yang sesungguhnya adalah pembahasasan tentang pengecualian pembebanan tanggung jawab pada direksi, yang dalam artikel ini disebut sebagai suatu bentuk perlindungan bagi direksi. Bagian ini sekaligus juga memperjelas penyerapan doktrin business judgment rule dalam hukum perusahaan Indonesia. Dalam dua bahasan terakhir ini akan disampaikan pula beberapa kasus relevan sebagaimana tadi disebutkan. Dengan demikian, pada bagian akhir artikel diharapkan diperoleh kesimpulan tentang tanggungjawab dan perlindungan hukum direksi. Sistematika ini sekaligus sebagai petunjuk bahwa artikel ini membatasi ruang lingkup bahasan tentang tanggung jawab dan perlindungan hukum direksi dalam pengurusan perseroan terbatas, sebagaimana yang menjadi judulnya yang bisa mengesankannya terlalu luas, pada halhal terkait doktrin business judgment rule dan kasus-kasus mutakhir yang relevan.

\section{B. Perseroan Terbatas dan Organ Direksi}

Perseroan terbatas merupakan badan hukum persekutuan modal yang melakukan kegiatan usaha dengan modal dasar yang seluruhnya terbagi dalam saham. ${ }^{7}$ Ia, sebagaimanabadan usahalainnya, setidaknya didirikan oleh dua orang, dikarenakan memang harus didirikan berdasarkan perjanjian. ${ }^{8}$ Dalam kegiatan perekonomian, perseroan

7 Pasal 1 angka 1 UUPT Tahun 2007: "Perseroan terbatas, yang selanjutnya disebut perseroan, adalah badan hukum yang merupakan persekutuan modal, didirikan berdasarkan perjanjian, melakukan kegiatan usaha dengan modal dasar yang seluruhnya terbagi dalam saham dan memenuhi persyaratan yang ditetapkan dalam Undang-Undang ini serta peraturan pelaksanaannya”.

8 Pendirian perseroan oleh setidak-tidaknya dua orang atau pihak merupakan syarat mutlak. Namun, demikian, dapat saja memang dalam perkembangannya salah satu pemegang saham menjual sahamnya kepada pemegang saham lainnya sehingga mengakibatkan kepemilikan tunggal. Dalam hal pemegang saham tunggal, maka kepadanya dibebankan tanggung jawab secara pribadi atas segala perikatan dan kerugian perseroan. UU juga mengharuskan pemegang saham tunggal untuk mengalihkan sebagian 
terbatas merupakan salah satu badan usaha yang dominan dalam artian banyak diminati. Hal ini menunjukkan tingkat keterpilihannya pada kalangan pelaku usaha. Di antara faktor yang mendorongnya adalah karena badan usaha ini memisahkan hak dan kewajiban para pengusaha selaku pemegang saham dengan hak dan kewajiban perusahaan. Adanya pemisahan hak dan kewajiban ini, yang lazim dipahami dengan pemisahan harta kekayaan dan tanggung jawabnya, menyebabkan eksistensi perseroan terbatas sebagai institusi ekonomi yang pada hakikatnya bukan semata menjalankan kegiatan usaha, melainkan juga lembaga ekonomi yang demokratis. ${ }^{9}$

Dengan begitu, dalam perseroan terbatas melekat karakter persekutuan modal dan pemisahan harta kekayaan. Karakteristik yang demikian itu menunjukkan bahwa perseroan terbatas tidak mementingkan sifat kepribadian para pemegang sahamnya. Karakteristik demikian juga menunjukkan perbedaannya secara substansial dengan badan usaha lainnya semisal persekutuan perdata. ${ }^{10}$

Dalamperseroanterbatas, sebagaimanajamakdiketahui, terdapat organ yang terdiri dari tiga: rapat umum pemegang saham (RUPS), direksi, dan dewan komisaris. Dari ketiganya, RUPS merupakan organ tertinggi yang mempunyai wewenang yang tidak diberikan kepada direksi atau dewan komisaris. ${ }^{11}$ Direksi sendiri merupakan

sahamnya kepada orang lain atau mengeluarkan saham baru kepada orang lain dalam jangka waktu enam bulan setelah kepemilikan tunggal. Apabila dalam jangka waktu tersebut tetap tidak terpenuhi, maka pemegang saham tunggal bertanggung jawab secara pribadi, dan atas permohonan pihak yang berkepentingan, pengadilan negeri dapat membubarkan perseroan tersebut. Lihat: Verti Tri Wahyuni, "Kepemilikan Tunggal Badan Hukum Perseroan Terbatas (PT)”, Jurnal Hukum Novelty, 8, 2 (2017), hlm. 213-214.

9 Johari Santoso, "Perseroan Terbatas sebagai Institusi Kegiatan Ekonomi yang Demokratis”, Jurnal Hukum Ius Quia Iustum, 7, 15 (2000), hlm. 194.

10 Ridwan Khairandy, "Karakter Hukum Perusahaan Perseroan dan Status Hukum Kekayaan yang Dimilikinya”, Jurnal Hukum Ius Quia Iustum, 20, 1 (2013), hlm. 90

11 Pasal 1 angka 4 UUPT Tahun 2007: "Rapat Umum Pemegang Saham, yang selanjutnya disebut RUPS, adalah Organ Perseroan yang mempunyai wewenang yang tidak diberikan kepada direksi atau dewan komisaris dalam batas yang ditentukan dalam Undang-Undang ini dan/atau anggaran 
"organ perseroan yang berwenang dan bertanggung jawab penuh atas pengurusan perseroan untuk kepentingan perseroan, sesuai dengan maksud dan tujuan perseroan serta mewakili perseroan, baik di dalam maupun di luar pengadilan sesuai dengan ketentuan anggaran dasar". ${ }^{12}$ Sedangkan dewan komisaris adalah "organ perseroan yang bertugas melakukan pengawasan secara umum dan/ atau khusus sesuai dengan anggaran dasar serta memberi nasihat kepada direksi”. ${ }^{13}$

Penjelasan tentang organ dalam perseroan tersebut memberitahu bahwa direksi merupakan organ yang penting dan strategis. ${ }^{14}$ Organ direksi merupakan organ yang melakukan atau menjalankan pengurusan perseroan. Ia dapat terpisah atau bukan bagian dari pemegang saham, sekalipun juga sering dijumpai direksi merupakan bagian dari pemegang saham. Dalam hal seseorang menjadi pemegang saham sekaligus direksi, kedudukan keduanya sesungguhnya bisa dibedakan. Sebagai pemegang saham, forumnya adalah RUPS; sementara sebagaidireksi forumnya adalah menjalankan pengurusan perseroan. Karena itu, tanpa mengeyampingkan peran organ lainnya, tidak keliru jika dikatakan peran direksi akan sangat menentukan maju dan mundurnya perseroan. Dikaitkan dengan tujuan perusahaan yaitu mencari keuntungan atau laba, maka peran direksi berarti akan menentukan keuntungan yang diperoleh perseroan, juga risiko kerugian yang bisa saja ditimbulkannya.

UUPT Tahun 2007 mengatur siapa saja yang bisa menjadi direksi

dasar”.

12 Pasal 1 angka 5 UUPT Tahun 2007.

13 Pasal 1 angka 6 UUPT Tahun 2007.

14 Karena itu kedudukan direksi sering dianggap sebagai posisi tertinggi dalam sebuah perseroan terbatas. Suatu anggapan, yang menurut Sujana Donandi Sinuraya tidak seutuhnya salah atau benar. Sebab, jika merujuk UUPT, maka organ tertinggi itu adalah RUPS, yang memiliki kewenangankewenangan utama dalam suatu perseroan, termasuk memilih dan memberhentikan direksi. Sebaliknya, jika melihat konteks berjalannya perseroan terutama dalam aktivitasnya sehari-hari, maka direksi memang menjadi yang tertinggi dalam berbagai pengambilan keputusan perseroan. Sujana Donandi Sinuraya, "Kedudukan Direksi dalam Perseroan Terbatas", https: / / www.indonesiana.id/ read/137713/ kedudukan-direksi-dalamperseroan-terbatas, 6/2/2020, diakses $2 / 5 / 2020$. 
suatu perseroan. Pada dasarnya siapa pun yang cakap hukum dapat menjadi direksi. Dalam hukum perdata Indonesia, cakap hukum berarti telah dewasa atau sudah menikah dan tidak berada di bawah pengampuan. Kedewasaan ditentukan oleh batasan usia, yaitu telah berusia 21 tahun, sedangkan pernikahan bisa saja terjadi pada usia sebelum 21 tahun, disebabkan syarat melangsungkannya adalah sudah berusia 19 tahun bagi laki-laki dan 16 tahun bagi perempuan. Belakangan, batas usia minimal melangsungkan pernikahan direvisi oleh Mahkamah Konstitusi menjadi 18 tahun.

Meski demikian, bahwa siapa pun yang sudah cakap hukum dapat menjadi direksi, UUPT Tahun 2007 juga memberi batasan. Mereka yang dalam lima tahun sebelum pengangkatannya pernah dinyatakan pailit, menjadi anggota direksi atau anggota dewan komisaris yang dinyatakan bersalah menyebabkan perseroan dinyatakan pailit, dan dihukum karena melakukan tindak pidana yang merugikan keuangan negara dan/atau yang berkaitan dengan sektor keuangan, merupakan orang-orang yang dikecualikan untuk bisa diangkat sebagai direksi. ${ }^{15}$ Hal demikian nampaknya agar siapa pun yang diangkat sebagai direksi merupakan orang-orang yang memiliki kualitas sekaligus reputasi dalam pengurusan suatu perseroan, sehingga apabila punya rekam jejak yang buruk dalam pengelolaan perseroan dan hal-hal yang terkait dengan sektor keuangan selama lima tahun terakhir, harus dikecualikan untuk dapat diangkat sebagai direksi.

Demikian juga, UUPT Tahun 2007 membebaskan direksi terdiri dari berapa orang. Bahkan, satu orang pun bisa menjadi direksi, tidak harus lebih. Pembatasan direksi harus terdiri minimal dua orang hanya berlaku apabila kegiatan perseroan berkaitan dengan menghimpun dan/atau mengelola dana masyarakat, menerbitkan surat pengakuan utang kepada masyarakat, atau perseroan terbuka.

15 Pasal 93 ayat (1) UUPT Tahun 2007. 


\section{Tanggung Jawab Direksi dalam Pengurusan Perseroan Terbatas}

Bagian ini ingin menjelaskan, mengapa direksi harus bertanggung jawab dalam pengurusan perseroan terbatas, dan bagaimana pula bentuk tanggung jawab tersebut. Sebagaimana disinggung pada awal tulisan, persoalan tanggung jawab sesungguhnya berkenaan dengan kewajiban seorang individu melaksanakan aktivitas yang ditugaskan kepadanya sebaik mungkin sesuai dengan kemampuannya. Dalam pengurusan perseroan, maka tanggung jawab berarti berkenaan dengan kewajiban direksi melakukan pengurusan perseroan sebagaimana tugas yang diembannya, baik berdasarkan ketentuan peraturan perundang-undangan maupun anggaran dasar suatu perseroan.

Persoalan tanggung jawab sendiri tidak terlepas dari persoalan kesadaran dan kebebasan. Adanya tanggung jawab di sini bermula dari adanya kesadaran dan kebebasan pada manusia, yang kemudian menimbulkan tanggung jawab. Dalam pandangan eksistensialisme, manusia dipahami mengada dengan kesadaran sebagai dirinya sendiri. Kesadaran manusia selalu disertai kebebasan, sebab tanpa kebebasan maka kesadaran manusia bahkan eksistensinya menjadi absurd. Dalam hal ini, manusia dalam membentuk dirinya sendiri mendapat kesempatan untuk setiap kali memilih apa yang baik dan apa yang kurang baik bagi dirinya sendiri. Karena itu, setiap pilihan yang diambil, melekat di sana tanggung jawab sebagai konsekuensinya. ${ }^{16}$ Dengan begitu, dapat dikatakan bahwa kesadaran dan tanggung jawab berhubungan dengan sikap dan tindakan manusia dalam mengisi ruang kebebasan yang dimiliki. Sikap dan tindakan yang diambil oleh setiap manusia tidak berdiri di ruang kosong, melainkan harus dipertanggungjawabkan terhadap nilai-nilai yang sebenarnya, terhadap tugas dan kewajibannya. ${ }^{17}$

Dalam kaitannya dengan tanggung jawab direksi dalam pengurusan perseroan, menjadi perlu ditelaah bukan saja soal

16 Dwi Siswanto, "Kesadaran dan Tanggung Jawab Pribadi dalam Humanisme Jean-Paul Sartre”, Jurnal Filsafat, Seri 28 (1997), hlm. 26.

17 Siswanto, "Kesadaran dan Tanggung Jawab Pribadi”, hlm. 31. 
tanggungjawabnya, tetapi juga kondisi yang membawa pada tanggung jawab tersebut, dalam hal ini "kesadaran" dan "kebebasan" dalam melakukan pengurusan perseroan. Ketiganya, yaitu "kesadaran", "kebebasan", dan "tanggung jawab", dalam hal ini perlu dilihat sebagai satu jalinan yang terkait. Karena konteksnya pengurusan perseroan, maka "kesadaran", "kebebasan" dan "tanggung jawab" ini dikaitkan dengan tugas dan kewajiban dalam melakukan pengurusan perseroan.

Dari banyak pengertian dan pemahaman tentang kesadaran, ${ }^{18}$ salah satunya menyebutnya sebagai kondisi internal manusia yang harus dibedakan dengan kondisi fisiknya. Ia merupakan penghubung antara stimulus yang diterima oleh seseorang, dan respons yang diberikannya. ${ }^{19}$ Karenanya, kesadaran sebagai kondisi internal tersebut akan memengaruhi tindakan manusia.

Sementara itu, kebebasan, antara lain dalam arti moral atau disebut kebebasan moral, dalam rumusan positif bermakna kemampuan manusia dalam memilih beberapa alternatif tindakan. Dalam rumusan berbeda, yaitu rumusan negatif, kebebasan moral berarti tidak adanya paksaan atau ancaman dalam melahirkan tindakan. Dengan begitu, kebebasan (moral) berarti kemampuan manusia dalam memilih berbagai alternatif tindakan secara merdeka tanpa suatu ancaman atau paksaan. ${ }^{20}$

Dalam kaitannya dengan pengurusan perseroan, uraian ringkas tentang kesadaran dan kebebasan ini ingin menyampaikan bahwa pengurusan perseroan oleh direksi berarti harus disertai dengan suatu kesadaran pada direksi tentang tugas dan kewajibannya sebagai direksi dalam mengelola perseroan. Kesadaran yang demikian penting sehingga tindak-tindakan yang dilakukannya sejalan dengan apa yang menjadi tugas dan kewajibannya. Di sisi lain, dengan kebebasan dimaksudkan bahwa tindakan-tindakan direksi dalam

18 Dicky Hastjarjo, “Sekilas tentang Kesadaran”, Buletin Psikologi, 13, 2 (2005): 79-90.

19 Reza A.A Wattimena, "Manusia dan Kesadaran", https://rumahfilsafat. $\mathrm{com} / 2009 / 02 / 15 /$ kesadaran-manusia/, 15/2/2009, diakses 2/5/2020.

20 A. Dardiri, "Sepintas tentang Arti Kebebasan Manusia dan Peranannya dalam Pertanggungjawaban Moral”, Jurnal Filsafat, Seri 10 (1992), hlm. 18. 
menjalankan pengurusan perseroan yang merupakan bagian dari kegiatan perekonomian akan mustahil bisa dilakukan jika tidak memiliki kebebasan dalam memilih berbagai alternatif tindakan. Meski demikian, kebebasan itu harus pula sejalan dengan ramburambu dalam pengurusan suatu perseroan, yang umumnya tertuang dalam suatu anggaran dasar perseroan, selain juga rambu dalam peraturan perundang-undangan. Oleh karenanya, perlu diuraikan lebih lanjut tentang tugas, kewajiban, dan rambu-rambu dalam menjalankan pengurusan perseroan.

Sebagaimana sebelumnya diuraikan, direksi dalam pengertian UUPT Tahun 2007 adalah organ perseroan yang berwenang dan bertanggung jawab penuh atas pengurusan perseroan untuk kepentingan perseroan. Dalam menjalankan perannya, direksi memiliki hubungan dengan perseroan yang didasarkan pada kepercayaan (fiduciary duty). Karena itu direksi dalam melakukan pengurusan perseroan harus bertolak dari landasan bahwa tugas dan kedudukan yang diperolehnya berdasarkan dua prinsip dasar, yaitu kepercayaan yang diberikan perseroan (fiduciary duty) dan tindakan yang dilandasi oleh kemampuan dan kehati-hatian (duty of skill and care). Prinsip-prinsip ini menuntut direksi untuk menjalankan pengurusan perseroan berdasarkan itikad baik, berhati-hati, dan semata-mata untuk kepentingan dan tujuan perseroan. ${ }^{21}$

Mengenai tugas dan tanggung jawab direksi, UUPT Tahun 2007 mengatur bahwa "Direksi menjalankan pengurusan perseroan untuk kepentingan perseroan dan sesuai dengan maksud dan tujuan perseroan". ${ }^{22}$ UUPT juga mengatur, direksi berwenang menjalankan pengurusan sesuai dengan kebijakan yang dipandang tepat, dalam batas yang ditentukan dalam undang-undang dan/atau anggaran dasar. ${ }^{23}$ Dalam Penjelasan UUPT disebutkan, ketentuan demikian "menugaskan direksi untuk mengurus perseroan yang, antara

21 Chatamarrasjid Ais, "Fiduciary Duty sebagai Standar Para Direksi dalam Melaksanakan Tugasnya”, Jurnal Hukum dan Pembangunan, 31, 1 (2001), hlm. 64.

22 Pasal 92 ayat (1) UUPT Tahun 2007.

23 Pasal 92 ayat (2) UUPT Tahun 2007. 
lain meliputi pengurusan sehari-hari dari perseroan". ${ }^{24}$ Sedangkan "kebijakan yang dipandang tepat" dijelaskan sebagai "kebijakan yang, antara lain didasarkan pada keahlian, peluang yang tersedia, dan kelaziman dalam dunia usaha yang sejenis", ${ }^{25}$

Ketentuan UUPT Tahun 2007 tentang tugas direksi yang demikian itu tentu masih menimbulkan pertanyaan tentang pengurusan perseroan, sekalipun disebutkan antara lain pengurusan sehari-hari perseroan. Kata "antara lain" sendiri menunjukkan bahwa pengurusan sehari-hari hanyalah bagian saja dari pengurusan perseroan, yang berarti juga ada pengurusan "yang bukan seharihari".

Dalam kaitannya dengan hukum, perbuatan mengurus perseroan ini, sebagaimana dijelaskan Nindyo Pramono, ${ }^{26}$ diatur oleh norma hukum melalui beheer van daden dan beschikking van daden. Beschikking van daden merupakan kaidah yang berisi larangan, baik yang terdapat dalam anggaran dasar maupun UUPT. Kaidah larangan tersebut dalam UUPT misalnya keharusan direksi meminta persetujuan RUPS, yang berarti larangan bagi direksi untuk mengambil keputusan sendiri dalam mengalihkan kekayaan dan menjadikan jaminan utang kekayaan perseroan. ${ }^{27}$ Menurut Nindyo, secara a contrario, kaidah yang tidak dirumuskan harus mendapat persetujuan RUPS atau dewan komisaris, baik dalam anggaran dasar maupun UUPT, termasuk dalam lingkup perbuatan yang biasa sehari-hari dilakukan oleh direksi dalam mengurus perseroan.

Sementara itu, terkait kewenangan direksi melakukan pengurusan berdasarkan kebijakan yang tepat, sebagaimana ketentuan Pasal 92 ayat 2 UUP Tahun 2007, yang dalam penjelasannya disebutkan

24 Penjelasan Pasal 92 ayat (1) UUPT Tahun 2007.

25 Penjelasan Pasal 92 ayat (2) UUPT Tahun 2007.

26 Nindyo Pramono, "Tanggung Jawab dan Kewajiban Pengurus PT (Bank) Menurut UU No. 40 Tahun 2007 tentang Perseroan Terbatas”, Buletin Hukum Perbankan dan Kebanksentralan, 5, 3 (2007), hlm. 18.

27 Pasal 102 ayat (1) UUPT Tahun 2007: "Direksi wajib meminta persetujuan RUPS untuk a. mengalihkan kekayaan perseroan, atau b. menjadikan jaminan utang kekayaan perseroan, yang merupakan lebih dari 50\% jumlah kekayaan bersih perseroan dalam satu transaksi atau lebih, baik yang berkaitan satu sama lain maupun tidak". 
antara lain kebijakan dalam kelaziman dalam dunia usaha sejenis, sesungguhnya sulit diberikan kriteria dan ukurannya. Karena itu, Nindyo mengatakan, kebijakan yang dipandang tepat ini sebaiknya dipahami sebagai kebijakan yang dapat mendatangkan keuntungan bagi perseroan, yaitu kebijakan yang berguna bagi kepentingan perseroan. ${ }^{28}$

Dikaitkan dengan uraian awal pada bagian ini, yang hendak melihat tanggung jawab direksi dalam satu rangkaian dengan kesadaran dan kebebasan yang mengawalinya terlebih dahulu, maka kesadaran dan kebebasan ini berarti suatu kesadaran direksi tentang kepercayaan (fiduciary) yang telah diberikan perseroan kepadanya untuk melakukan pengurusan perseroan dan kesadaran akan tugasnya sebagai direksi untuk melakukan pengurusan tersebut berdasarkan kemampuan atau keahlian dan kehati-hatian (duty of skill and care). Karena itu, pengurusan perseroan berdasarkan itikad baik, kehatihati, dan semata-mata untuk kepentingan dan tujuan perseroan, mesti menjadi kesadaran direksi dalam melaksanakan tugas, peran, dan kewajibannya. Dalam kesadaran melaksanakan perannya tersebut, direksi juga memiliki kebebasan, yaitu kebebasan untuk melakukan pengurusan berdasarkan kebijakan yang dipandangnya tepat, yang ini antara lain merujuk pada pertimbangan kelaziman dalam dunia usaha. Kebebasan ini memang ada batasannya, yaitu pada pengurusan tertentu yang berdasarkan ketentuan UUPT atau anggaran dasar perseroan memerlukan persetujuan RUPS atau dewan komisaris. Namun untuk pengurusan yang berdasarkan UUPT dan anggaran dasar tidak memerlukan persetujuan organ perseroan lainnya, terutama dalam pengurusan sehari-hari, direksi sesungguhnya memiliki kebebasan sepenuhnya. Meski demikian, kebebasan tersebut juga tetap harus disertai pertimbangan kebijakan

28 Pramono, “Tanggung Jawab dan Kewajiban Pengurus PT”, hlm. 19. Nindyo juga menjelaskan, dalam perkembangan sekarang yang memandang penting penerapan tata kelola perusahaan yang baik (good corporate governance), kepentingan PT tidak terbatas pada kepentingan PT sendiri atau dalam pandangan klasik sebelumnya kepentingan pemegang saham, melainkan juga kepentingan karyawan, kepentingan pihak ketiga atau kreditur, kepentingan negara, dan sebagainya (hlm. 20). 
yang dinilai tepat dan lazim. Ini berarti, kebebasan direksi juga harus dilakukan sesuai keahlian atau kemampuan, itikad baik, dan kehatihatian. Dengan kesadaran dan kebebasan yang demikian itu, direksi dapat dibebani tanggung jawab.

Kalau demikian, bahwa tangung jawab merupakan konsekuensi dari kesadaran dan kebebasan, lalu bagaimanakah tanggung jawab direksi dalam pengurusan perseroan. Pertama, perlu disampaikan kembali, sebagaimana definisi yang diberikan oleh UUPT, bahwa direksi merupakan organ yang berwenang dan bertanggung jawab penuh atas pengurusan perseroan. Dari sini terlihat jelas bahwa tanggung jawab merupakan satu rangkaian dengan kewenangan. Adanya kewenangan yang dimiliki direksi diikuti atau menimbulkan tanggung jawab padanya. Jika dengan kewenangan maka direksi memiliki kekuasaan melakukan pengurusan, dengan pembebanan tanggung jawab maka direksi diharuskan menjalankan kekuasaan tersebut berdasarkan rambu-rambu yang berlaku.

Dalam UUPT Tahun 2007 disebutkan, "direksi bertanggung jawab penuh atas pengurusan perseroan". ${ }^{29}$ Pengurusan tersebut "wajib dilaksanakan setiap anggota direksi dengan itikad baik dan penuh tanggung jawab". ${ }^{30}$ Apabila perseroan mengalami kerugian, maka setiap anggota direksi bertanggung jawab penuh secara pribadi apabila yang bersangkutan bersalah atau lalai dalam menjalankan tugasnya. ${ }^{31}$ Dalam hal direksi terdiri dari dua orang atau lebih, maka tanggung jawab tersebut berlaku secara tanggung renteng bagi setiap anggota direksi. ${ }^{32}$

Namun demikian, seorang direksi dapat dikecualikan dari pembebanan tanggung jawab atas kerugian yang dialami perseroan, yaitu apabila ia dapat membuktikan empat hal berikut: ${ }^{33}$

1. kerugian tersebut bukan karena kesalahan atau kelalaiannya;

2. telah melakukan pengurusan dengan itikad baik dan kehati-

29 Pasal 97 ayat (1) UUPT Tahun 2007.

30 Pasal 97 ayat (2) UUPT Tahun 2007.

31 Pasal 97 ayat (3) UUPT Tahun 2007.

32 Pasal 97 ayat (4) UUPT Tahun 2007.

33 Pasal 97 ayat (5) UUPT Tahun 2007. 
hatian untuk kepentingan dan sesuai dengan maksud dan tujuan perseroan;

3. tidak mempunyai benturan kepentingan baik langsung maupun tidak langsung atas tindakan pengurusan yang mengakibatkan kerugian; dan

4. telah mengambil tindakan untuk mencegah timbul atau berlanjutnya kerugian tersebut.

Di luar empat kondisi tersebut, yang berlaku secara komulatif, maka direksi harus bertanggung jawab terhadap segala pengurusan perseroan. Terhadap yang pertama, yaitu kerugian yang bukan saja diakibatkan oleh kesalahan tetapi juga kelalaian, hal ini dikarenakan prinsip tanggung jawab dalam perbuatan hukum menghendaki subyek hukum untuk tidak melakukan kesalahan dan kelalaian. Dalam hukum perdata, yang aturan dasarnya tertuang dalam Kitab Undang-undang Hukum Perdata, tanggung jawab disebutkan di sana bukan saja karena kesalahan, melainkan juga kelalaian. ${ }^{34}$

Dengan demikian, pertanggungjawaban direksi dalam pengurusan perseroan dapat bersifat pribadi dan juga kolektif. Pertanggungjawaban direksi bersifat pribadi apabila kerugian yang dialami perseroan disebabkan kesalahan atau kelalaian individu anggota direksi. Sedangkan apabila kerugian perseroan diakibatkan adanya kesalahan atau kelalaian dalam keputusan atau tindakan dewan direksi, yang berarti secara bersama-sama, maka pertanggungjawabannya pun bersifat kolektif.

Dari uraian bentuk tanggung jawab ini terlihat bahwa seorang direksi dikenai tanggung jawab tidaklah semata karena kedudukannya sebagai direksi, melainkan juga tindakan-tindakan yang dilakukannya dalam pengurusan tersebut. Ada tiga peran yang dilakukan direksi dalam tindakan perusahaan sehingga dikenai tanggung jawab:

34 Pasal 1365 KUHPerdata: "Setiap orang bertanggung jawab tidak saja untuk kerugian yang disebabkan perbuatannya, tetapi juga untuk kerugian yang disebabkan kelalaian atau kurang hati-hatinya”. Pasal 1367 ayat (1) KUHPerdata: "Seorang tidak saja bertanggung jawab untuk kerugian yang disebabkan perbuatannya sendiri, tetapi juga untuk kerugian yang disebabkan perbuatan orang-orang yang menjadi tanggungannya atau disebabkan oleh barang-barang yang berada di bawah penguasaannya”. 
mengizinkan perbuatan tersebut; meratifikasi perbuatan tersebut; danikutberpartisipasi dengan cara apapun dalam perbuatan tersebut. ${ }^{35}$ Karena peran dan keterlibatannya itu, maka seorang direksi harus bertanggung terhadap pengurusan perseroan.

\section{Perlindungan Hukum Direksi dalam Pengurusan Perseroan}

Menurut Satjipto Rahardjo, perlindungan hukum adalah upaya mengorganisasi berbagai kepentingan dalam masyarakat supaya tidak bertubrukan atau ditekan sekecil-kecilnya, sehingga hak-hak yang diakui atau diberikan oleh hukum bisa dinikmati. ${ }^{36}$ Dalam hak yang diakui atau diberikan hukum tersebut, suatu kepentingan merupakan sasarannya. ${ }^{37}$ Karena itu, perlindungan hukum itu terkait dengan hak dan lebih spesifik lagi kepentingan pihak-pihak terkait. Kepentingan tersebut, yang merupakan sasaran hak, diakui dan diberikan oleh hukum sehingga bisa dinikmati.

Apabila pemahaman perlindungan hukum yang demikian itu digunakan untuk menelaah perlindungan hukum direksi dalam pengurusan perseroan, maka ia berarti suatu kepentingan atau hak yang bisa dinikmati oleh direksi dalam melaksanakan tugas dan perannya mengelola atau mengurus perseroan. Kepentingan atau hak tersebut dalam hal ini diakui atau diberikan oleh hukum. Uraian berikut ini akan melihat, bagaimana hukum mengakui atau memberikan kepentingan atau hak kepada direksi dalam melakukan pengurusan perseroan. Karena bahasan perlindungan hukum di sini merupakan satu kesatuan dengan tanggung jawab direksi, maka

35 Bismar Nasution, "Pertanggungjawaban Direksi dalam Pengelolaan Perseroan”, makalah Seminar Nasional dalam Rangka Menciptakan Good Corporate Governance pada Sistem Pengelolaan dan Pembinaan PT (Persero)BUMN “OptimalisasiSistem Pengelolaan, Pengawasan, Pembinaan dan Pertanggungjawaban Keberadaan PT (Persero) di Lingkungan BUMN Ditinjau dari Aspek Hukum dan Transparansi”, diselenggarakan oleh Inti Sarana Informatika, Jakarta, 8/3/2007.

36 Satjipto Rahardjo, Ilmu Hukum (Bandung: Citra Aditya Bakti, cetakan keenam, 2006), hlm. 53-54.

37 Rahardjo, Ilmu Hukum, hlm. 54. 
kepentingan atau hak yang diakui atau diberikan hukum tersebut harus pula dikaitkan dengan tanggung jawab direksi, sebagaimana yang dibahas pada bagian sebelumnya.

Dalam UUPT Tahun 2007, kepentingan atau hak yang bisa dinikmati oleh direksi dalam kaitannya dengan tanggung jawabnya mengurus perseroan, ialah sebagaimana terlihat dalam ketentuan Pasal 97 ayat (5). Pada Pasal tersebut disebutkan, anggota direksi tidak dapat dipertanggungjawabkan atas kerugian yang dialami perseroan apabila dapat membuktikan 1) kerugian tersebut bukan karena kesalahan atau kelalaiannya; 2) telah melakukan pengurusan dengan itikad baik dan kehati-hatian untuk kepentingan dan sesuai dengan maksud dan tujuan perseroan; 3) tidak mempunyai benturan kepentingan baik langsung maupun tidak langsung atas tindakan pengurusan yang mengakibatkan kerugian; dan 4) telah mengambil tindakan untuk mencegah timbul atau berlanjutnya kerugian tersebut.

Hal itu berarti, direksi yang semula disebutkan harus bertanggung jawab atas semua pengurusan perseroan, termasuk ketika perseroan mengalamai kerugian, bisa dibebaskan dari tanggung jawab itu. Pembebasan tanggung jawab itu diberikan kepada direksi setelah dibuktikan pengurusan perseroan dilakukan secara profesional atau keahlian $^{38}$ (sehingga tidak salah atau lalai), itikad baik, kehati-hatian, tidak punya benturan kepentingan pribadi, dan melakukan tidakan pencegahan. Kondisi pembebasan tanggung jawab ini pada dasarnya adalah suatu kepentingan atau hak yang diberikan oleh hukum kepada direksi dalam menjalankan tugas pengurusan perseroan setelah direksi bekerja berdasarkan rambu-rambu yang berlaku, dan karenanya bisa disebut sebagai bentuk perlindungan hukum kepada direksi.

Perlindungan hukum terhadap anggota direksi dalam pengurusan perseroan merupakan hal yang sangat penting, karena direksi sebagai organ yang melakukan pengurusan memiliki otoritas dan kewenangan mengambil keputusan dan kebijakan terhadap aktivitas

38 Suatu tindakan yang dilakukan berdasarkan keahlian merupakan salah satu kriteria suatu tindakan yang profesional. 
perseroan terutama aktivitas sehari-hari. Dalamkegiatan atau aktivitas perekonomian, berbagai keputusan dan kebijakan bisa menimbulkan kemungkinan-kemungkinan: keuntungan dan kerugian bagi perseroan. Ditilik dari tujuan perusahaan, maka mendapatkan keuntungan atau laba memang tujuan utamanya. Namun demikian, dalam kegiatan perekonomian, kerugian merupakan bagian dari risiko yang bisa saja dialami. Karena itu, keputusan dan kebijakan direksi sesungguhnya keputusan dan kebijakan yang penting dan strategis sekaligus berisiko tinggi.

Dalam hal risiko itu yang terjadi, yaitu suatu kerugian, maka jelas sangat diperlukan suatu perlindungan hukum bagi direksi sehingga tidak dibebani tanggung jawab yang berlebihan. Kepribadian perusahaan pada perseroan terbatas mencegah direksi untuk bertanggung jawab terhadap kewajiban perusahaan. ${ }^{39}$ Namun hal ini tidak berarti direksi bebas sepenuhnya dari tanggung jawab atas risiko kerugian yang dialami perseroan. Pembebasan tanggung jawab hanya berlaku apabila prinsip itikad baik, kehati-hatian, upaya pencegahan, dan profesionalitas (keahlian) sudah diterapkan. Hal ini penting agar direksi tidak mengambil keputusan dan kebijakan secara sembrono atau sesukanya saja, tetapi juga memerhatikan prinsip-prinsip dalam pengelolaan perusahaan (profesionalitas, itikad baik, kehati-hatian).

Tidak mudah untuk menentukan apakah seorang direksi telah melaksanakan tugas berdasarkan itikad baik. Hal ini terkait dengan makna dan tolok ukur dari itikad baik itu sendiri. Dengan meminjam penjelasan itikad baik dalam hukum perikatan, maka dapat dikatakan bahwa hal ini terkait dengan kejujuran dan kepatutan. Kejujuran itu terletak pada hati sanubari, yang berarti bersifat subyektif; sedangkan kepatutan terletak pada keadaan sekitar hubungan hukum yang berlangsung, yang berarti bersifat obyektif. ${ }^{40}$ Dalam kontrak, itikad baik mengacu pada sifatnya yang obyektif. Hal ini berarti suatu

39 Freddy Haris, "Pemisahan Tanggung Jawab Direksi Perseroan Tebatas", Jurnal Hukum dan Pembangunan, 35, 1 (2005), hlm. 92

40 Muhammad Arifin, "Itikad Baik sebagai Asas Pokok dalam Hukum Perikatan Nasional”, Jurnal Hukum dan Pembangunan, 14, 4 (1984), hlm. 359. 
perilaku dikatakan telah beritikad baik apabila sesuai dengan normanorma obyektif yang tidak tertulis yang sudah menjadi norma hukum sebagai suatu sumber hukum tersendiri. Norma ini dikatakan obyektif bukan didasarkan pada anggapan para pihak sendiri, melainkan sesuai dengan anggapan umum tentang itikad baik tersebut. ${ }^{41}$

Demikian pula dengan apa yang dimaksud dengan kehatihatian, juga tidak mudah menetapkan batasannya. Secara umum kehati-hatian dapat dimaknai sebagai perhatian terhadap risiko atau bijaksana dalam melakukan dealing. Dalam suatu investasi, kehatihatian berarti tidak melaksanakan aktivitas dengan sekadar mengejar keuntungan tertinggi tanpa memperhatikan risiko keamanan dari pihak yang memberikan amanah. ${ }^{42}$ Dari sini berarti kehati-hatian juga terkait dengan suatu aktivitas perekonomian yang tidak sekadar mengejar keuntungan tetapi juga mempertimbangkan risikonya.

Bentuk perlindungan hukum kepada direksi dalam melakukan pengurusan, sebagaimana ketentuan Pasal 97 ayat ayat (5) UUPT Tahun 2007, merupakan cermin dari prinsip doktrin business judgement rule, yaitu aturan yang memberikan kekebalan atau perlindungan bagi manajemen perseroan dari setiap tanggung jawab yang lahir sebagai akibat transaksi atau kegiatan yang dilakukan olehnya sesuai dengan batas-batas kewenangan dan kekuasaan yang diberikan kepadanya, dengan mempertimbangkan bahwa kegiatan tersebut telah dilakukan dengan memperhatikan standar kehati-hatian dan itikad baik. $^{43}$

Menurut Ridwan Khairandy, business judgement rule merupakan doktrin yang mengajarkan bahwa direksi perseroan tidak bertanggung jawab atas kerugian yang timbul dari suatu tindakan pengambilan putusan, apabila tindakan tersebut didasarkan pada iktikad baik

41 Ridwan Khairandy, "Makna, Tolok Ukur, Pemahaman, dan Sikap Pengadilan di Indonesia terhadap Iktikad Baik dalam Pelaksanaan Kontrak", Jurnal Hukum Ius Quia Iustum, 16, edisi khusus (2009), hlm. 63.

42 Paripurna P. Sugarda, "Kontrak Standar: Antara Prinsip Kehati-hatian Bank dan Perlindungan Nasabah Debitur”, Mimbar Hukum, 20, 2 (2008), hlm. 196.

43 Gunawan Widjaja, 150 Tanya Jawab tentang Perseron Terbatas (Jakarta: Forum Sahabat, 2008), hlm. 66. 
dan hati-hati. Direksi mendapat perlindungan hukum tanpa perlu memperoleh pembenaran dari pemegang saham atau pegadilan atas keputusan yang diambilnya dalam konteks pengelolaan perusahaan. ${ }^{44}$

Jadi, business judgement rule adalah perlindungan hukum bagi direktur dan jajarannya daripertanggungjawaban atas setiap kebijakan atau keputusan bisnis atau transaksi yang mengakibatkan kerugian bagi perusahaan, selama kebijakan atau keputusan bisnis atau transaksi bisnis tersebut dilakukan dengan itikad baik, penuh kehatihatian, kejujuran, sejalan dengan tanggungjawab dan wewenangnya. ${ }^{45}$ Dengan demikian, business judgement rule merupakan aturan (doctrine atau presumption) yang memberikan kekebalan atau perlindungan bagi manajemen perseroan (direksi) dari setiap tanggung jawab yang lahir sebagai akibat dari transaksi atau kegiatan yang dilakukan olehnya sesuai dengan batas-batas kewenangan dan kekuasaan yang diberikan kepadanya, dengan pertimbangan bahwa kegiatan tersebut telah dilakukan dengan memperhatikan standar kehati-hatian dan itikad baik serta bertanggung jawab. ${ }^{46}$

Business judgement rule mendorong direksi untuk lebih berani mengambil risiko daripada terlalu berhati-hati, sehingga perseroan tidak berjalan. Prinsip ini mencerminkan asumsi bahwa pengadilan tidak dapat dapat membuat keputusan yang lebih baik dalam bidang bisnis daripada direksi. Para hakim umumnya tidak memiliki keterampilan bisnis dan mulai mempelajari permasalahan setelah terjadi fakta-fakta. ${ }^{47}$

\section{E. Beberapa Kasus terkait Tanggung Jawab dan Perlindungan Hukum Direksi}

Selain mendasarkan pada peraturan hukum dan literatur terkait,

44 Ridwan Khairandy, Hukum Perseroan Terbatas (Yogyakarta: Penerbit FH UII Press, 2014), hlm. 234.

45 Rudhi Prasetya, Perseroan Terbatas: Teori dan Praktik (Jakarta: Sinar Grafika, 2014), hlm. 151.

46 Prasetya, Perseroan Terbatas, hlm. 151.

47 Khairandy, Hukum Perseroan Terbatas, hlm. 235. 
pembahasan tentang tanggung jawab dan perlindungan hukum direksi dalam pengurusan perseroan juga perlu menelaahnya dari kasus konkrit. Pembahasan tanggung jawab dan perlindungan hukum direksi ini dari segi aturan hukum dan juga doktrin sudah dilakukan pada bagian terdahulu, sehingga pada bagian berikut akan dipaparkan dari beberapa kasus konkrit. Uraian tentang kasuskasus konkrit ini menjadi penting dalam upaya mengidentifikasi pemaknaan peran direksi dalam perseroan, tanggung jawabnya, juga perlindungan hukumnya.

Pertama, perkara keputusan direksi Pertamina melalui anak perusahaannya PT. Pertamina Hulu Energi (PHE) untuk melakukan akuisisi saham 10 persen pada Roc Oil Company Limited (ROC, Ltd) Australia pada 27 Mei 2009. Perkara ini diajukan ke pengadilan sebagai tindak pidana korupsi dengan terdakwa mantan direktur utama Pertamina Karen Agustiawan. Akuisi ini sendiri dilakukan untuk investasi participating interest dalam rangka menggarap lapangan atau blok Basker Manta Gummy (BMG) Australia. Dalam perkembangannya, blok BMG tidak bisa menghasilkan minyak mentah sesuai yang ditargetkan, yaitu 812 barel perhari, melainkan hanya 252 barel perharinya. Pada 5 November 2010, blok BMG bahkan ditutup setelah ROC memutuskan penghentian produksi minyak mentah. Dari akuisisi untuk kepentingan investasi ini, Pertamina mengalami kerugian mencapai Rp. 568 miliar.

Tindakan Karen sebagai Direktur Utama Pertaminan tersebut oleh Pengadilan Tindak Pidana Korupsi pada Pengadilan Negeri Jakarta Pusat dinyatakan sebagai tindak pidana korupsi yang dilakukan bersama-sama. ${ }^{48}$ Putusan ini diperkuat pada tingkat banding, dengan tambahan pertimbangan bahwa kedudukan Karen sebagai Direktur Utama memiliki tugas dan tanggung jawab dalam mengendalikan dan memonitor kegiatan akuisisi, dan dalam

48 Putusan Pengadilan Tindak Pidana Korupsi pada Pengadilan Negeri Jakarta Pusat Nomor 15/Pid.Sus-TPK/2019/PN.Jkt.Pst, perkara tindak pidana korupsi terhadap Karen Agustiawan. Dalam putusan ini, salah satu hakim berbeda pendapat (dissenting opinion), yang menyatakan bahwa tindakan terdakwa merupakan tindakan bisnis, bukan untuk kepentingan pribadi sehingga bukan merupakan kerugian negara. 
akuisisi ini dianggap telah mengabaikan laporan tim eksternal yang menyatakan akuisisi ini sangat berisiko tinggi. ${ }^{49}$ Pada tingkat kasasi, tindakan yang dilakukan Karen disebut sebagai tindakan bisnis dan bagian dari bussines judgement rule, sehingga putusan direksi dalam suatu aktivitas perseroan tidak dapat diganggu gugat oleh siapapun. Kendati putusan itu pada akhirnya menimbulkan kerugian bagi perseroan, hal itu merupakan risiko bisnis. ${ }^{50}$

Dalam perkara Karen ini, maka terlihat pengadilan melalui hakimnya berbeda pendapat terkait tindakan direktur yang mengakibatkan kerugian pada perseroan, dan dalam kasus ini bahkan dianggap menyebabkan kerugian negara. Pada mulanya, melalui Pengadilan Negeri dan Pengadilan Tinggi, tindakan bisnis berupa akuisisi yang kemudian berdampak kerugian, dianggap sebagai tindakan direksi yang mengabaikan tugas dan kewajibannya. Namun demikian Mahkamah Agung pada akhirnya menilai tindakan demikian sebagai tindakan bisnis direksi yang kemudian berdampak kerugian. Sebagai tindakan bisnis, yang memang memiliki risiko kerugian, maka keputusan dalam tindakan direksi ini pada akhirnya dinyatakan tidak dapat diganggu gugat, sebagaimana doktrin business judgment rule.

Kedua, perkara Benjamin Widjaja dan Sianna Kusuma Widjaja (keduanya pemegang saham pada PT. Necis Indah Cemerlang) melawan Julius Widjaja (Direksi PT. Necis Indah Cemerlang), Heryati Suryaman (Komisaris PT. Necis Indah Cemerlang), dan PT. Danamon Indonesia, Tbk. Dalam perkara ini, Benjamin dan Sianna memersoalkan tindakan Julius selaku direksi dan Heryati selaku komisaris yang mengadakan perjanjian transaksi valuta asing dengan

49 Putusan Pengadilan Tindak Pidana Korupsi pada Pengadilan Tinggi DKI Jakarta Nomor 34/Pid.Sus-TPK/2019/PT.DKI, perkara tindak pidana korupsi pada tingkat banding terhadap Karen Agustiawan.

50 Demikian keterangan yang disampaikan Juru Bicara Mahkamah Agung Andi Samsan Nganro dengan merujuk putusan kasasi pada 10/3/2020. Kompas.Com, "Eks Dirut Pertamina Karen Agustiawan Bebas dari Penjara”, https:/ / nasional.kompas.com/ read/2020/03/10/20160201/ eksdirut-pertamina-karen-agustiawan-bebas-dari-penjara, 10/3/2020, diakses $11 / 6 / 2020$. 
PT. Danamon, disebabkan tindakan tersebut tanpa persetujuan Rapat Umum Pemegang Saham dan tidak sesuai dengan tujuan dan kegiatan usaha perseroan. Pada Akta Pendirian Perseroan diketahui bahwa PT. Necis ini bergerak pada bidang perdagangan, industri tekstil dan garmen.

Tindakan direksi dan komisaris tersebut oleh Pengadilan Negeri Bale Bandung ${ }^{51}$ dinyatakan sebagai perbuatan melawan hukum, sehingga perjanjian dan pemberian fasilitas kredit yang sudah dilakukan dinyatakan batal demi hukum. Putusan ini diperkuat oleh Pengadilan Tinggi Bandung ${ }^{52}$ dan Mahkamah Agung. ${ }^{53}$ Dengan demikian, suatu tindakan direksi, sebagaimana yang menjadi fokus artikel ini, yang tidak sesuai dengan Akta Pendirian, tidak bisa berlindung diri sebagai tindakan bisnis yang memang memiliki risiko. Sekalipun tindakan direksi dalam perkara ini juga berkaitan dengan bisnis, yaitu melakukan perjanjian transaksi valuta asing, tindakan bisnis ini sesungguhnya di luar dari kegiatan usaha perseroan, sebagaimana yang ditetapkan dalam Akta Pendirian. Dalam konteks demikian, tindakan direksi berarti tidak mendapatkan perlindungan hukum sebagaimana doktrin business judgment rule, melainkan harus menjadi tanggung jawabnya sebagai pengurus.

Ketiga, perkara keputusan direktur utama PT. Merpati Nusantara Airline (Persero) (PT MNA), Hotasi D.P. Nababan, yang melakukan penyewaan pesawat Boeing 737 seri 400 dan 500 dengan Thirdstne Aircraft Leasing Group (TALG) Washington DC. pada 2006, dan telah melakukan pembayaran security deposit sejumlah 1 juta dolar Amerika. Keputusan direksi ini dipersoalkan sebagai perkara tindak pidana korupsi karena pesawat yang disewa tidak juga kunjung datang, sementara security deposit tidak juga bisa ditarik kembali. Keputusan direksi ini dipermasalahkan karena pengambilan

51 Merujuk pada Putusan Kasasi Mahkamah Agung, Putusan Pengadilan Negeri ini bernomor 06/Pdt.G/2009/PN.BB tanggal 8/5/2009.

52 Merujuk pada Putusan Kasasi Mahkamah Agung, Putusan Pengadilan Tinggi ini bernomor 270/Pdt/2009/PT.BDG tanggal 20/11/2009.

53 Putusan Kasasi Mahkamah Agung Nomor $1855 \mathrm{~K} / \mathrm{Pdt} / 2010$, perkara perdata antara Benjamin Widjaja dan Sianna Kusuma Widjaja melawan Julius Widjaja, Heryati Suryaman, dan PT. Danamon Indonesia, Tbk. 
keputusannya dianggap tidak sesuai, antara lain, dengan Rencana Kerja Anggaran Perusahaan (RKAP) 2006 yang terkait kebijakan pengadaan pesawat.

Keputusan direksi ini oleh Pengadilan Tindak Pidana Korupsi pada Pengadilan Negeri Jakarta Pusat, dengan satu hakim anggota yang berbeda pendapat (dissenting opinion), dinyatakan bukan sebagai perbuatan melawan hukum. Tindakan direksi dianggap sebagai tindakan bisnis yang dilakukan dengan hati-hati, beritikad baik, dan demi kepentingan perusahaan. Pengadilan juga mengutip doktrin business judgment rule dalam mempertimbangkannya, bahwa tolok ukur tindakan bisnis telah dilakukan secara hati-hati adalah memiliki informasi tentang masalah yang diputus, tidak memiliki kepentingan dengan keputusan tersebut, dan memiliki dasar rasional bahwa keputusan yang diambil merupakan yang terbaik bagi perusahaan. ${ }^{54}$ Terkait dengan security deposit yang belum kembali, dan ini yang dianggap sebagai kerugian perusahaan, Pengadilan juga mempertimbangkan tindakan perusahaan sejauh ini yang mengupayakannya kembali, antara lain melalui gugatan ke Pengadilan US Court for the District of Columbia, Washington D.C., yang melalui keputusannya Pengadilan US Court ini mewajibkan TALG Inc. untuk mengembalikan security deposit kepada PT MNA. ${ }^{55}$

Putusan Pengadilan Tindak Pidana Korupsi pada Pengadilan Negeri Jakarta Pusat tersebut dalam tingkat kasasi dibatalkan oleh Mahkamah Agung. Salah satu alasannya, dan ini yang hanya relevan dengan tema pembahasan artikel ini, ialah bahwa tindakan bisnis direksi ini tidak sesuai dengan RKAP PT MNA Tahun 2006. Meskipun pada akhirnya pada 11 Oktober 2006 ada keputusan RUPS tentang RKAP yang baru, tindakan bisnis direksi melakukan penyewaan sendiri ternyata sudah dimulai prosesnya dua bulan sebelumnya. Demikian juga dengan security deposit, dinilai Mahkamah tidak

54 Putusan Pengadilan Tindak Pidana Korupsi pada Pengadilan Negeri Jakarta Pusat Nomor 36/Pid.B/TPK/2012/PN.JKT.PST., perkara tindak pidana korupsi dengan terdakwa Hotasi D.P. Nababan, hlm. 113-114.

55 Putusan Pengadilan Tindak Pidana Korupsi pada Pengadilan Negeri Jakarta Pusat Nomor 36/Pid.B/TPK/2012/PN.JKT.PST., perkara tindak pidana korupsi dengan terdakwa Hotasi D.P. Nababan, hlm. 122. 
dilakukan melalui mekanisme yang benar, karena dibayarkan pada saat TALG belum melakukan purchase agreement dengan East Dover. Padahal sesuai dengan kesepakatan (Lease Agreement Summary of Term, LASOT), pembayaran security deposit sehari setelah adanya purchase agreement. ${ }^{56}$

Dalam kasus keputusan direktur utama PT MNA ini memang tidak terkait dengan UUPT. Namun demikian, dari kasus ini bisa diperoleh pelajaran penting tentang keputusan bisnis dalam suatu perusahaan. Sekalipun ada doktrin business judgment rule yang dapat melindungi keputusan bisnis yang dilakukan oleh direksi, keputusan bisnis itu sendiri harus diambil dengan proses dan alasan yang tepat. Tindakan bisnis direksi PT MNA pada akhirnya dinilai Mahkamah Agung tidak tepat karena tidak sesuai RKAP Tahun 2006 yang menjadi pedoman dalam tindakan bisnis direksi pada 2006. Meski PT MNA sebenarnya memenangkan gugatan pada Pengadilan di Amerika agar security deposit yang telah diberikan kepada TALG kembali, yang ini antara lain menjadi pertimbangan keputusan Pengadilan Negeri untuk membebaskan direksi dari perbuatan melawan hukum, oleh Mahkamah hal ini tampaknya bukan sebagai alasan yang membebaskan. Mahkamah lebih melihat pada keputusan bisnis itu sendiri telah sesuai atau tidak dengan rambu-rambu yang berlaku dalam perusahaan, antara lain sebagaimana yang tercantum dalam RKAP.

Dari tiga kasus yang telah dipaparkan, diketahui dalam praktik peradilan tidak mudah untuk menentukan kapan direksi harus bertanggung jawab atas keputusan atau tindakan direksi dalam melakukan pengurusan, dan kapan pula direksi dibebaskan dari tanggung jawab tersebut, yang dalam konteks artikel ini disebut sebagai suatu perlindungan hukum. Perlindungan hukum bagi direksi ini sendiri, dalam hukum perusahaan, selain didasarkan pada ketentuan hukum, juga diperkuat oleh doktrin business judgment rule. Dari tiga kasus tersebut, kasus kedua barangkali yang relatif mudah menentukan tanggung jawabnya. Hal ini dikarenakan dalam kasus tersebut direksi

56 Putusan Kasasi Mahkamah Agung Nomor 417K/Pid.Sus/2014, perkara tindak pidana korupsi dengan terdakwa Hotasi D.P. Nababan, hlm. 58. 
melakukan kegiatan bisnis yang tidak sesuai dengan ruang lingkup kegiatan perusahaan sebagaimana tercantm dalam Akta Pendirian.

Sementara itu, pada kasus pertama dan ketiga, antar tingkat pengadilan bahkan berbeda penilaian tentang tindakan bisnis dari direksi. Pada kasus pertama, pengadilan pertama dan pengadilan banding mengategorikan tindakan bisnis berupa akuisisi yang berdampak kerugian pada perusahaan sebagai perbuatan melawan hukum. Sebaliknya, pada tingkat kasasi, hal demikian dianggap sebagai bagian dari risiko bisnis. Demikian pula pada kasus ketiga. Pengadilan pertama mengategorikan tindakan bisnis penyewaan pesawat dan pembayaran security deposit sebagai keputusan bisnis yang bukan perbuatan melawan hukum, sekalipun perusahaan menjadi dirugikan karena pesawat yang disewa tidak pernah datang dan security deposit tidak juga kembali. Keputusan ini dianulir pada tingkat kasasi, dengan membebankan tanggung jawab kepada direksi atas kerugian tersebut, disebabkan tidak sejalan dengan rencana bisnis perusahaan pada tahun tersebut.

\section{F. Kesimpulan}

Artikel ini menyimpulkan, pertama, tanggung jawab direksi dalam pengurusan perseroan terbatas merupakan satu rangkaian dan sekaligus konsekuensi dari "kesadaran" dan "kebebasan" yang melekat dalam tugas-tugas direksi. Kesadaran yang dimaksudkan di sini adalah kesadaran direksi tentang kepercayaan (fiduciary) yang telah diberikan perseroan kepadanya untuk melakukan pengurusan perseroan dan kesadaran akan tugasnya sebagai direksi untuk melakukan pengurusan tersebut berdasarkan kemampuan atau keahlian dan kehati-hatian (duty of skill and care), sedangkan yang dimaksud kebebasan adalah kebebasan direksi untuk melakukan pengurusan berdasarkan kebijakan yang dipandang tepat. Dalam hal direksi menjalankan kesadaran dan kebebasan yang demikian itu tidak disertai keahlian atau kemampuan, itikad baik, dan kehati-hatian sehingga berakibat kerugian pada perseroan, maka direksi harus dibebani tanggung jawab penuh. Tanggung jawab direksi ini dapat bersifat 
pribadi dan kolektif. Pertanggungjawaban direksi bersifat pribadi apabila kerugian yang dialami perseroan disebabkan kesalahan atau kelalaian individu anggota direksi, sedangkan pertanggungjawaban secara kolektif apabila kerugian perseroan diakibatkan adanya kesalahan atau kelalaian dalam keputusan atau tindakan dewan direksi. Kedua, perlindungan hukum bagi direksi dalam melakukan pengurusan perseroan diperlukan karena peran penting dan strategis yang dimilikinya. Namun demikian, perlindungan hukum ini akan diperoleh oleh direksi manakala telah melakukan pengurusan secara profesional atau keahlian (sehingga tidak salah atau lalai), itikad baik, kehati-hatian, tidak punya benturan kepentingan pribadi, dan telah melakukan tidakan pencegahan kerugian. Dalam hukum perusahaan, perlindungan hukum semacam ini sejalan dengan doktrin business judgment rule, bahwa direksi perseroan tidak bertanggung jawab atas kerugian yang timbul dari suatu keputusan atau tindakan bisnis yang didasarkan pada iktikad baik, penuh kehati-hatian, kejujuran, serta sejalan dengan wewenangnya. Ketiga, dalam kajian kasus konkret yang diajukan ke pengadilan, tidak mudah menentukan kapan direksi harus bertanggung jawab dan kapan pula direksi mendapatkan perlindungan hukum sehingga dibebaskan dari tanggung jawab. Dari tiga kasus yang dikaji dalam artikel ini, terlihat tanggung jawab itu akan dibebankan pada direksi manakala tindakan bisnisnya tidak dalam ruang lingkup kegiatan usaha sebagaimana yang tertuang dalam Akta Pendirian. Dua dari tiga kasus yang dibahas juga memperlihatkan perbedaan penilaian antar tingkat pengadilan dan tentu berdampak pula pada putusannya terkait keputusan bisnis yang masih dalam ruang lingkup kegiatan perusahaan namun berakibat kerugian.

\section{Daftar Pustaka}

\section{Artikel, Buku, dan Laporan}

Ais, Chatamarrasjid. "Fiduciary Duty sebagai Standar Para Direksi dalam Melaksanakan Tugasnya”. Jurnal Hukum dan Pembangunan, 31, 1 (2001): 63-72. DOI: 10.21143/jhp.vol31.no1.1315.

Arifin, Muhammad. "Itikad Baik sebagai Asas Pokok dalam Hukum 
Perikatan Nasional". Jurnal Hukum dan Pembangunan, 14, 4 (1984): 358-361. DOI: 10.21143/jhp.vol14.no4.1047.

Dardiri, A. "Sepintas tentang Arti Kebebasan Manusia dan Peranannya dalam Pertanggungjawaban Moral”. Jurnal Filsafat, Seri 10 (1992): 17-26. DOI: $10.22146 /$ jf.31437.

Haris, Freddy. "Pemisahan Tanggung Jawab Direksi Perseroan Tebatas". Jurnal Hukum dan Pembangunan, 35, 1 (2005): 87-104. DOI: 10.21143 /jhp.vol35.no1.1457.

Hastjarjo, Dicky. "Sekilas tentang Kesadaran”. Buletin Psikologi, 13, 2 (2005): 79-90. DOI: 10.22146/bpsi.7478.

Khairandy, Ridwan. Hukum Perseroan Terbatas. Yogyakarta: Penerbit FH UII Press, 2014.

Khairandy, Ridwan. "Karakter Hukum Perusahaan Perseroan dan Status Hukum Kekayaan yang Dimilikinya”. Jurnal Hukum Ius Quia Iustum, 20, 1 (2013): 81-97. DOI: 10.20885/iustum.vol20. iss1.art5.

Khairandy, Ridwan. "Makna, Tolok Ukur, Pemahaman, dan Sikap Pengadilan di Indonesia terhadap Iktikad Baik dalam Pelaksanaan Kontrak”. Jurnal Hukum Ius Quia Iustum, 16, edisi khusus (2009): 51-71.

Kompas.Com. "Eks Dirut Pertamina Karen Agustiawan Bebas dari Penjara”. Https://nasional.kompas.com/ $\mathrm{read} / 2020 / 03 / 10 / 20160201 /$ eks-dirut-pertamina-karenagustiawan-bebas-dari-penjara, 10/3/2020. Diakses 11/6/2020.

Nasution, Bismar. "Pertanggungjawaban Direksi dalam Pengelolaan Perseroan”. Makalah Seminar Nasional dalam Rangka Menciptakan Good Corporate Governance pada Sistem Pengelolaan dan Pembinaan PT (Persero) BUMN "Optimalisasi Sistem Pengelolaan, Pengawasan, Pembinaan dan Pertanggungjawaban Keberadaan PT (Persero) di Lingkungan BUMN Ditinjau dari Aspek Hukum dan Transparansi”, diselenggarakan oleh Inti Sarana Informatika, Jakarta, 8/3/2007.

Pramono, Nindyo. “Tanggung Jawab dan Kewajiban Pengurus PT (Bank) Menurut UU No. 40 Tahun 2007 tentang Perseroan 
Terbatas". Buletin Hukum Perbankan dan Kebanksentralan, 5, 3 (2007): 15-30.

Prasetya, Rudhi. Perseroan Terbatas: Teori dan Praktik. Jakarta: Sinar Grafika, 2014.

Rahardjo, Satjipto. Ilmu Hukum. Bandung: Citra Aditya Bakti, cetakan keenam, 2006.

Santoso, Johari. "Perseroan Terbatas sebagai Institusi Kegiatan Ekonomi yang Demokratis”. Jurnal Hukum Ius Quia Iustum, 7, 15 (2000): 194-203. DOI: 10.20885/iustum.vol7.iss15.art15.

Sinuraya, Sujana Donandi. "Kedudukan Direksi dalam Perseroan Terbatas”. https:/ / www.indonesiana.id/ read/137713/ kedudukan-direksi-dalam-perseroan-terbatas, $\quad 6 / 2 / 2020$. Diakses 2/5/2020.

Siswanto, Dwi. "Kesadaran dan Tanggung Jawab Pribadi dalam Humanisme Jean-Paul Sartre”. Jurnal Filsafat, Seri 28 (1997): 2532. DOI: $10.22146 /$ jf.31659.

Sugarda, Paripurna P. "Kontrak Standar: Antara Prinsip Kehati-hatian Bank dan Perlindungan Nasabah Debitur". Mimbar Hukum, 20, 2 (2008): 193-410. DOI: 10.22146/jmh.16302.

Wahyuni, Verti Tri. "Kepemilikan Tunggal Badan Hukum Perseroan Terbatas (PT)”. Jurnal Hukum Novelty, 8, 2 (2017): 201-215. DOI: 10.26555/ novelty.v8i2.a6914.

Wattimena, Reza A.A. "Manusia dan Kesadaran". Https:// rumahfilsafat.com/2009/02/15/kesadaran-manusia/, 15/2/2009. Diakses 2/5/2020.

Widjaja, Gunawan. 150 Tanya Jawab tentang Perseroan Terbatas. Jakarta: Forum Sahabat, 2008.

Winardi. Asas-asas Manajemen. Bandung: Alumni, 1983.

\section{Peraturan dan Putusan Hukum}

Republik Indonesia. Undang-Undang Nomor 40 Tahun 2007 tentang

Perseroan Terbatas. Lembaran Negara Tahun 2007 Nomor 106, Tambahan Lembaran Negara Nomor 4756.

Republik Indonesia, Mahkamah Agung. Putusan Kasasi Nomor

$1855 \mathrm{~K} / \mathrm{Pdt} / 2010$, perkara perdata antara Benjamin Widjaja 
dan Sianna Kusuma Widjaja melawan Julius Widjaja, Heryati Suryaman, dan PT. Danamon Indonesia, Tbk.

Republik Indonesia, Mahkamah Agung. Putusan Kasasi Mahkamah Agung Nomor 417K/Pid.Sus/2014, perkara tindak pidana korupsi dengan terdakwa Hotasi D.P. Nababan.

Republik Indonesia, Pengadilan Tindak Pidana Korupsi pada Pengadilan Negeri Jakarta Pusat. Putusan Nomor 36/Pid.B/ TPK/2012/PN.JKT.PST, perkara tindak pidana korupsi dengan terdakwa Hotasi D.P. Nababan.

Republik Indonesia, Pengadilan Tindak Pidana Korupsi pada Pengadilan Negeri Jakarta Pusat. Putusan Nomor 15/Pid.SusTPK/2019/PN.Jkt.Pst, perkara tindak pidana korupsi terhadap Karen Agustiawan.

Republik Indonesia, Pengadilan Tindak Pidana Korupsi pada Pengadilan Tinggi DKI Jakarta. Putusan Nomor 34/Pid.SusTPK/2019/PT.DKI, perkara tindak pidana korupsi pada tingkat banding terhadap Karen Agustiawan. 